\title{
Evolution of the Brazilian Education in the XX century
}

\author{
Luan Henrique dos Santos Oliveira \\ Liaison Officer and Satellite Project \\ Management Officer | Brasil \\ Andean Road Countries for Science and Technology
}

The first higher education schools were founded in Brazil in 1808 with the arrival of the Portuguese royal family to the country (Durham, 2004). Pending the republic proclamation in 1889 , higher education developed very slowly.

To the end of the XIX century, there were only 24 higher education institutions in Brazil with about 10,000 students. From then on, private enterprise created its own higher education institutions and in the next 30 years the educational system expanded considerably from 24 isolated schools to 133 .

The idea of university mobilized generations of proponents and critics of this teaching form. The project elaborated by the secular intellectual elite defended the public university in opposition to the model of isolated institutions and proposed the research institutionalization.

In the 1920s, the debate about the universities' creation was no longer restricted to strictly political issues as in the past, but to the concept of university and its functions in the society. It was based on these debates that, in 1931, a wide educational reform was promoted, which became known as the Francisco Campos Reform (the country's first Education Minister), authorizing and regulating the functioning of universities, although the reform represented a breakthrough, it didn't meet the main movement flag which was giving public exclusivity to higher education.

The period from 1945 to 1968 witnessed the fight of the student movement and young professors in the defense of public education (Thapliyal, 2013) it was in question the discussion about the reform of the whole education system, but especially the university. This debate allowed the discussion of the Guidelines and Bases of Education Law (LDB), approved by Congress in 1961, which, unlike the 1931 reform, did not insist that higher education should be organized preferably in universities. 


\section{JOURNAL OF LATIN AMERICAN SCIENCES AND CULTURE}

Vol. 1 - 2019

Universidad Privada del Valle - Bolivia

https://doi.org/10.52428/2788891.v1i1.38

The demand pressure led to an extraordinary expansion in higher education (especially private faculties and universities) in the period from 1960 to 1980, with enrollment numbers jumping from approximately 200000 to 1,4 million, but from 1980 onwards there was a progressive reduction in demand for higher education due to the retention and evasion of high school students.

Whereas in 1980, about $11 \%$ of the vacancies offered in higher education courses were not met, in 1990 the proportion passed to $19 \%$. As it was commented this low percentage was not conditioned by lack of vacancies in higher education, but by the secondary education numbers.

In 1996, a new LDB was published, which governs the Brazilian school system in the present time, now with compulsory free primary and secondary education (Stanek, 2013). With this measure it was hoped to increase the number of university students in the country, since the educational bottleneck was being affected with the evasion of primary and secondary education students.

Between the years 2000 to date, according to the Brazilian Institute of Geography and Statistics (IBGE), there was an increase in the population percentage with higher education diplomas: from $4.4 \%$ to $15 \%$.

If the higher education diploma had traditionally been a distinctive symbol of the ruling classes, in the last decade the data reveals a change, making higher education accessible and essential to those who want opportunities in an increasingly competitive labor market, but research shows that the percentage of people with higher education in the country is still low and the incentive to higher education is still necessary (Norões \& McCowan, 2016).

\section{REFERENCES}

Durham, E. R. (2004). Higher education in Brazil: public and private. The challenges of education in Brazil, 147-178.

Norões, K., \& McCowan, T. (2016). The challenge of widening participation to higher education in Brazil: Injustices, innovations, and outcomes. In Widening Higher Education Participation (pp. 63-80). Chandos Publishing.

Stanek, C. (2013). The educational system of Brazil. IEM Spotlight, 10(1), 1-6.

Thapliyal, N. (2013). Reframing the public in public education: The Landless Workers Movement (MST) and adult education in Brazil. Journal for Critical Education Policy Studies (JCEPS), 11 (4). 
JOURNAL OF LATIN AMERICAN SCIENCES AND CULTURE

Vol. 1 - 2019

Universidad Privada del Valle - Bolivia

https://doi.org/10.52428/2788891.v1i1.38

Fuentes de financiamiento: Esta investigación fue financiada con fondos del autor.

Declaración de conflicto de intereses: El autor declara que no tiene ningún conflicto de interés.

Copyright (c) 2021 Luan Henrique dos Santos Oliveira

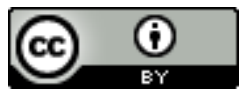

Este texto está protegido por una licencia CreativeCommons 4.0

Usted es libre para Compartir — copiar y redistribuir el material en cualquier medio o formato - y Adaptar el documento —remezclar, transformar y crear a partir del material — para cualquier propósito, incluso pa ra fines comerciales, siempre que cumpla la condición de:

Atribución: Usted debe dar crédito a la obra original de manera adecuada, proporcionar un enlace a la licencia, e indicar si se han realizado cambios. Puede hacerlo en cualquier forma razonable, pero no de forma tal que sugiera que tiene el apoyo del licenciante o lo recibe por el uso que hace de la obra.

$\underline{\text { Resumendelicencia - Textocompletodelalicencia }}$ 